\title{
ANALISIS EXPERIENTIAL MARKETING DAN LOYALITAS PELANGGAN JASA WISATA (Studi pada Taman Rekreasi Sengkaling Malang)
}

\author{
Rohmat Dwi Jatmiko dan Sri Nastiti Andharini \\ Fakultas Ekonomi dan Bisnis, Universitas Muhammadiyah Malang, Indonesia \\ Email: jetto@umm.ac.id; nandharini@yahoo.com
}

\begin{abstract}
Abstrak
Penelitian tentang experiential marketing dikaitkan dengan loyalitas pelanggan pada obyek wisata belum banyak dilakukan. Penelitian ini bertujuan menguji pengaruh simultan dan parsial dimensi experiential marketing: sense, feel, think, act, dan relate terhadap loyalitas pengunjung. Regresi berganda digunakan untuk analisis data. F-test menemukan experiential marketing berpengaruh positif signifikan terhadap loyalitas pelanggan. $t$-test menemukan feel dan sense berpengaruh postif signifikan terhadap loyalitas pelanggan, sedang think, act, dan relate berpengaruh positif tidak signifikan terhadap loyalitas pelanggan.
\end{abstract}

Kata Kunci: Experiential Marketing, Loyalitas Pelanggan, Jasa Wisata.

\begin{abstract}
Study associated experiential marketing on tourism customer loyalty has't been widely applied. This study examines the simultaneous and partial impact of experiential marketing dimensions: sense, feel, think, act, and relate to customer loyalty. Multiple regressions were used for data analysis. F-test found that experiential marketing has positive and significant impact on customer loyalty. $t$-test found that feel and sense a significant positive impact on customer loyalty, while think, act, and relate insignificant positive impact on customer loyalty.
\end{abstract}

Keywords: Experiential Marketing, Costomer Loyalty, Tourism Service.

\section{PENDAHULUAN}

Konsep experiential marketing terus berkembang dan menimbulkan tantangan baru bagi perusahaan yang menerapkannya. Hal ini sangat menarik, karena konsep yang masih tergolong baru pada dunia marketing ini berperan sangat strategis dalam meningkatkan jumlah konsumen dan mempertahankan loyalitas konsumen. Penelitian yang mengkaitkan experiential marketing dengan loyalitas pelanggan telah banyak dilakukan pada berbagai jenis perusahaan. Chen et al., (2008) mengkaitkan experiential marketing dengan loyalitas pelanggan pada virtual customer, Febiana (2009) pada suatu Bank Swasta di Semarang, Utami (2009) pada produk sepeda motor merek Yamaha, Reinhard (2011) pada sebuah Toko Roti di Medan, Sekar dan Kalakumari (2011) tentang build brand store di India. Penelitian yang mengkaitkan experiential marketing dengan loyalitas pengunjung pada obyek wisata relatip jarang dilakukan.

Taman Rekreasi Sengkaling berada di Malang yang merupakan daerah yang memiliki udara sejuk dan memiliki banyak potensi obyek wisata alam maupun buatan. Pengembangan taman wisata dilakukan untuk menarik lebih banyak pengunjung atau wisatawan dengan menyediakan sarana dan prasarana untuk menampung berbagai aktivitas wisatawan seperti melakukan adventure vacation, green tour, biofour, nature vacation, berolahraga di alam terbuka, menyegarkan jiwa, serta pemulihan kesehatan. Pengembangan Taman Rekreasi Sengkaling diorientasikan untuk meningkatkan kualitas manajemen, kualitas pelayanan dan fisik yang disuguhkan untuk pengunjung, serta untuk menangkap keinginan pasar, yaitu perilaku wisatawan itu sendiri. Letak yang strategis dan mudah terjangkau, menjadikan Taman Rekreasi Sengkaling dikunjungi oleh wisatawan baik dari dan/atau luar Jawa Timur. Taman Rekreasi Sengkaling memiliki luas \pm 10.5 hektar dengan daya tarik utama kolam, perahu buatan di tengah kolam, serta keindahan panorama alam dengan tapak yang berkontur. Setiap tahun jumlah wisatawan yang mengunjungi obyek wisata ini mencapai lebih dari 1.2 juta pengunjung. Fenomena ini menunjukkan bahwa minat masyarakat pada obyek wisata ini cukup 
antusias, dan hal ini diikuti dengan peningkatan kualitas sarana dan pelayanan rekreasi (Wulan, 2003).

Taman Rekreasi Sengkaling Malang menawarkan jasa pariwisata alam dengan disertai nilai tambah berupa suasana keasrian alam, fasilitas bangunan fisik, desain interior dan eksterior arsitektur bangunan yang unik, serta kenyamanan fasilitas penunjang yang ditawarkan kepada para pengunjung yang diharapkan dapat menimbulkan pengalaman dan kesan tersendiri bagi para pengunjung. Taman Rekreasi Sengkaling Malang tentu tidak lepas dari persaingan bisnis yang semakin ketat. Obyek wisata di Malang terus bermunculan dan berpotensi menjadi pesaing baru bagi Taman Rekreasi Sengkaling. Manajemen Taman Rekreasi Sengkaling Malang melakukan pengembangan wahana dan pelayanan yang bertujuan untuk menciptakan pengalaman mengesankan dan mendalam bagi pengunjung selama menikmati fasilitas Taman Rekreasi Sengkaling Malang.

Dari sudut pandang pemasaran maka yang menjadi pertanyaan adalah, sebagai obyek atau tujuan wisata, apakah wahana dan pelayanan Taman Rekreasi Sengkaling Malang mampu menciptakan pengalaman yang mengesankan bagi pengunjung, baik yang berupa pengalaman panca indera, pengalaman perasaan, dan pengalaman pikiran. Menurut Schmitt (1999), upaya penciptaan pengalaman konsumen dikenal sebagai experiential marketing. Menurut Alma (2011), konsumen yang memperoleh pengalaman yang mengesankan selama menikmati produk/jasa suatu perusahaan tidak hanya akan menjadi konsumen yang loyal tapi juga bersedia menyebarkan informasi mengenai produk perusahaan secara word of mouth.

Penelitian ini dilakukan pada saat kondisi normal. Yang dimaksud kondisi normal dalam penelitian ini adalah kunjungan wisata pada hari libur akhir pekan (Sabtu dan Minggu), bukan pada saat masa liburan, baik liburan sekolah, libur nasional, cuti bersama, libur hari raya, dan sebagainya. Pengunjung yang menjadi obyek populasi dalam penelitian adalah pengunjung kelompok usia remaja, dan lebih khusus lagi adalah remaja pelajar tingkat SLTA dan mahasiswa yang berkunjung ke Taman Rekreasi Sengkaling atas inisiatip sendiri, tidak ikut dalam rombongan wisatawan tertentu, serta tidak bersama keluarga. Pada kondisi normal, Taman Rekreasi Sengkaling ramai dikunjungi oleh wisatawan, terutama anak-anak muda remaja usia sekolah dan mahasiswa. Permasalahan yang akan diteliti dalam penelitian ini adalah apakah pada saat berkunjung dan menikmati pelayanan dan wahana rekreasi di Taman Rekreasi Sengkaling para pengunjung memperoleh pengalaman mengesankan dan muncul keinginan untuk melakukan kunjungan ulang di masa men- datang. Secara spesifik, dirumuskan pertanyaan penelitian apakah experiential marketing berpengaruh terhadap loyalitas pengunjung Taman Rekreasi Sengkaling Malang?

Penelitian ini bertujuan menguji pengaruh simultan dan parsial dimensi experiential marketing terhadap loyalitas pengunjung Taman Rekreasi Sengkaling Malang.

\section{LANDASAN TEORI DAN HIPOTESIS}

Dalam literatur manajemen pemasaran jasa, terutama yang dimotori oleh Parasuraman et al., (1988) bahwa suatu perusahaan dapat memiliki keunggulan bersaing apabila mampu memberikan pelayanan yang bermutu dan dapat memuaskan pelanggan. Menurut Verhoef et al. (2009); Parasuraman et al. (1988), kurang mempertimbangkan konstruk pengalaman dalam hubungan kualitas jasa dengan kepuasan pelanggan. Menurut Verhoef et al. (2009), pengalaman pelanggan seharusnya dianggap sebagai variabel terpisah dari kualitas jasa dan kepuasan pelanggan. Dalam mengkonsumsi jasa dan sekaligus memproduksi jasa tertentu di mana konsumen atau pelanggan harus mendatangi dan berinteraksi dengan penyedia jasa, maka pelanggan akan memiliki aspek pengalaman (experience). Menurut Schmitt (1999), pengalaman pelanggan harus dikelola dengan baik oleh perusahaan. Menurut Andreani (2007), dalam konsep experiential marketing, organisasi-organisasi biasanya berusaha membidik aspek pengalaman emosional dan rasional dari pelanggan, karena kedua aspek tersebut umumnya mampu memberikan efek yang luar biasa dalam pemasaran, terutama kepuasan dan loyalitas pelanggan.

Schmitt (1999) telah mengeksplorasi bagaimana perusahaan-perusahaan menciptakan experiential marketing dengan mempertimbangkan lima elemen dasar yaitu rasa (sense), perasaan (feel), berpikir (think), bertindak (act), dan berhubungan (relate) dengan suatu perusahaan dan mereknya. Tidak seperti dalam pemasaran tradisional bahwa perusahaan dapat mendapatkan keunggulan bersaing bila mampu memuaskan pelanggan melalui pelayanan yang bermutu. Dalam konsep experiential marketing, perusahaan-perusahaan harus bersaing dengan menciptakan pengalaman yang memuaskan, dan perusahaan harus memadukan kelima elemen dasar experiential marketing untuk mendeteksi proses pembelian oleh konsumen.

Customer experience berasal dari aktivitas interaksi antara seorang pelanggan dengan suatu produk, perusahaan, atau bagian dari organisasi yang memancing reaksi pelanggan. Pengalaman pelanggan 
bersifat pribadi dan menyiratkan keterlibatan pelanggan pada tingkat yang berbeda dalam aspek rasional, emosional, sensorik, fisik, dan spiritualnya (Verhoef et al., 2009). Selanjutnya, Verhoef et al. (2009) menyatakan bahwa pengalaman pelanggan merupakan respon internal dan subjektif dari para pelanggan setelah melakukan kontak langsung atau tidak langsung dengan perusahaan. Kontak langsung umumnya dimulai oleh pelanggan dan terjadi dalam proses pembelian, atau dalam proses sedang menikmati layanan. Sementara itu, kontak tidak langsung sering melibatkan pertemuan yang tidak direncanakan dengan perwakilan dari perusahaan, layanan atau merek dan biasanya dalam bentuk rekomendasi atau kritik word-of-mouth (WOM), iklan, berita, ulasan dan sebagainya.

Customer experience bersifat holistik dan mencakup berbagai respon kognitif, afektif, emosional, sosial, dan fisik dari pelanggan terhadap perusahaan. Customer experience tidak hanya diciptakan oleh elemen-elemen yang dapat dikontrol oleh perusahaan (misalnya: layanan tatap-muka, suasana perusahaan/ toko, dan harga), tetapi juga oleh unsur-unsur yang berada di luar kendali perusahaan (misalnya: pengaruh orang lain, tujuan pembelian). Selain itu, pengalaman pelanggan mencakup pengalaman total yang mencakup tahap-tahap dalam pencarian, pembelian, konsumsi, dan purna jual, serta sangat mungkin melibatkan beberapa saluran distribusi.

Sejahtera (2010) menemukan bahwa experiential marketing mencakup sense, feel, think, act, dan relate, berpengaruh positif dan signifikan terhadap loyalitas pelanggan, di mana variabel sense sebagai variabel yang dominan mempengaruhi loyalitas pelanggan. Experience menurut definisi Schmitt (1999) adalah kejadian-kejadian yang terjadi sebagai tanggapan stimulasi atau rangsangan, contohnya sebagaimana diciptakan oleh usaha-usaha sebelum dan sesudah pembelian. Experience seringkali merupakan hasil dari observasi langsung dan atau partisipasi dari kegiatan-kegiatan, baik merupakan kenyataan, angan-angan, maupun virtual. Dengan demikian seorang pemasar perlu menciptakan lingkungan dan pengaturan yang tepat agar dapat menghasilkan customer experience yang diinginkan. Kartajaya (dalam Sejahtera, 2010) mendefinisikan experiential marketing sebagai suatu konsep pemasaran yang bertujuan untuk membentuk konsumen-konsumen yang loyal dengan menyentuh emosi mereka dan memberikan suatu feeling yang positif terhadap produk dan service. Dalam pendekatan experiential marketing produk dan layanan harus mampu membangkitkan sensasi dan pengalaman yang dapat menjadi basis loyalitas pengunjung.
Schmitt (1999) menyatakan bahwa sasaran dari experiential marketing adalah untuk memberi pengalaman kepada konsumen ialah melalui lima tipe pengalaman, yaitu sebagai berikut: (1) Think. Esensi dari think marketing adalah menuntut pemikiran kreatif konsumen tentang perusahaan dan merek. Dengan berfikir (think) dapat merangsang kemampuan intelektual dan kreatifitas seseorang. (2) Feel. Feel dapat menyentuh inner feelings dan emosi, dengan sasaran membangkitkan pengalaman afektif, sehingga ada rasa gembira dan bangga. Dalam menyentuh inner feelings, perusahaan perlu mempertimbangkan kondisi mood dan emosi konsumen atau pelanggan. (3) Sense. Sense dapat menciptakan sensory experiences melalui indera penglihatan, suara, sentuhan, perasaan, dan penciuman, yang memberikan kesan keindahan, kesenangan, kepuasan, melalui adanya stimuli (rangsangan), proses, dan consequences (akibat). (4) Act. Act marketing didesain untuk menciptakan pengalaman konsumen dalam hubungannya dengan physical body, lifestyle, dan interaksi dengan orang lain. (5) Relate. Relate marketing merupakan kombinasi think, feel, sense, dan act marketing yang bertujuan untuk mengkaitkan individu dengan sesuatu yang berada di luar dirinya, dengan orang lain, kelompok-kelompok sosial lainnya dalam pekerjaan, etnis, atau gaya hidup, dan bahkan dengan ruang lingkup sosial yang lebih luas, seperti negara, masyarakat, dan budaya.

Hasan (2009) mendefinisikan loyalitas konsumen sebagai orang yang membeli, khususnya yang membeli secara teratur dan berulang-ulang. Pelanggan dikatakan loyal bila pelanggan tersebut secara terus-menerus atau berulang kali datang ke suatu tempat yang sama untuk memuaskan keinginannya dengan memiliki suatu produk atau mendapatkan suatu jasa dan membayar produk atau jasa tersebut. Barnes (2003) mendefinisikan loyalitas sebagai akumulasi lamanya konsumen berbisnis dan melakukan pembelian yang berulang dengan perusahaan. Komponen utama loyalitas terdiri dari waktu, kontinuitas, dan lamanya hubungan antara konsumen dan perusahaan. Loyalitas dibentuk terlebih dahulu dengan menciptakan nilai pelanggan. Dengan menawarkan nilai yang semakin meningkat kepada konsumen, yaitu nilai yang lebih baik dari apa yang mereka peroleh di tempat lain, berarti perusahaan memberikan kontribusi pada keputusan konsumen untuk tetap loyal kepada perusahaan, dan karena itu mengubah mereka menjadi konsumen yang lebih berharga (Barnes, 2003). Penelitian ini menggunakan konsep Schmitt (1999) untuk mengukur experiential marketing modules yang terdiri dari sense (panca indera), feel (perasaan), think (berfikir), act (tindakan), dan relate (hubungan). 
Reinhard (2011) meneliti pengaruh strategi experiential marketing terhadap customer loyalty pada konsumen Toko Roti di Medan, menyimpulkan bahwa strategic experiential marketing yang diukur berdasarkan sense marketing, feel marketing, think marketing, act marketing dan relate marketing, berpengaruh positif dan signifikan pada Customer Loyalty, di mana sense marketing dimensi yang dominan mempengaruhi customer loyalty. Yulianto (2010) menemukan bahwa terdapat korelasi yang kuat antara experiential marketing dengan loyalitas pelanggan dan memiliki hubungan positif dan signifikan di antara keduanya. Chen et al. (2008) menemukan bahwa elemen-elemen experiential marketing yang terdiri dari sense, feel, think, act, dan relate berpengaruh positif terhadap loyalitas pelanggan Online atau Virtual Customer.

Sekar dan Kalakumari (2011) menyatakan bahwa experiential marketing memberikan kesempatan kepada pelanggan dengan cara sensorik untuk terlibat dan berinteraksi dengan merek, produk, dan jasa. Experiential Marketing merujuk pada "pengalaman pelanggan yang sebenarnya terhadap merek, produk/jasa yang mendorong penjualan dan meningkatkan kesadaran dan citra merek. Terdapat perbedaan di antara konsumen berkaitan dengan pemahaman, pengalaman, dan manfaat terhadap fitur atau tampilan suatu produk/jasa. Experiential marketing merupakan alat yang paling mujarab untuk memenangkan kepercayaan merek dari pelanggan. Pengalaman terhadap suatu merek dapat berasal dari sensasi, perasaan, persepsi, dan respon perilaku yang ditimbulkan oleh rangsangan yang berkaitan dengan merek (brand-related). Rini (2009) menemukan bahwa dalam experiential marketing, konsumen bukan hanya dilihat dari sisi rasional saja melainkan juga dari sisi emosionalnya. Perusahaan tidak seharusnya memperlakukan konsumen hanya sebagai pembuat keputusan yang rasional tetapi konsumen lebih menginginkan untuk dihibur, dirangsang serta dipengaruhi secara emosional dan ditantang secara kreatif.

Selanjutnya, Sekar dan Kalakumari (2011) menyatakan bahwa experiential branding merupakan suatu proses yang mana merek membuat dan mendorong interaksi sensorik dengan konsumen dalam semua aspek brand experience yang secara emosional mempengaruhi preferensi konsumen dan untuk secara aktif membentuk persepsinya terhadap merek. Interaksi sensorik konsumen mencakup unsurunsur komunikasi, ruang merek (brand space), serta produk dan layanan. Unsur-unsur tersebut secara bersama-sama mempengaruhi ekuitas merek. Aspekaspek yang berkaitan dengan senyuman, keharuman, sentuhan, rasa, kehangatan dapat menambah niat (intention) pembelian ulang dan pembelian yang tidak direncanakan (impulse buying). Pengalaman positif perlu dilembagakan dalam sistem sehingga semua titik sentuh memberikan semangat atau spirit terhadap merek. Singkat kata, experiential marketing merupakan instrumen yang mujarab untuk membantu perusahaan memanipulasi keputusan pembelian oleh konsumen.

Febiana (2009) menguji pengaruh keunggulan atribut layanan, nilai nasabah dan citra perusahaan terhadap experiential marketing dan dampaknya kepada peningkatan loyalitas nasabah Bank BUKOPIN Semarang mengindikasikan bahwa untuk meningkatkan loyalitas nasabah, manajemen perusahaan perlu memperhatikan faktor-faktor seperti keunggulan atribut layanan, nilai nasabah, citra perusahaan, dan experiential marketing, karena faktor-faktor tersebut terbukti mempengaruhi tinggi rendahnya loyalitas nasabah. Sementara itu, Utami (2009) menemukan bahwa dimensi experiential marketing yang terdiri dari sense, feel, think, act, dan relate berpengaruh positif terhadap experiential marketing, dan menemukan bahwa experiential marketing berpengaruh positif dan signifikan terhadap brand loyalty pada konsumen sepeda motor Yamaha di Kota Semarang. Lin (2011) menyimpulkan bahwa experience and satisfaction are important influence factors for visitor loyalty.

$\mathrm{H}_{1}$ : Experiential marketing berpengaruh postif dan signifikan terhadap loyalitas pengunjung Taman Rekreasi Sengkaling Malang.

$\mathrm{H}_{2}$ : Dimensi experiential marketing yang terdiri dari sense, feel, think, act, dan relatesecara parsial berpengaruh postif dan signifikan terhadap loyalitas pengunjung Taman Rekreasi Sengkaling Malang.

\section{METODE PENELITIAN}

Desain penelitian adalah eksplanatif berdasarkan data survey. Populasi penelitian adalah para pengunjung kelompok usia remaja, terutama pelajar tingkat SLTA dan mahasiswa yang membeli tiket dan sedang berada di dalam area Taman Rekreasi Sengkaling Malang selama periode pengambilan data. Sampel yang diambil sebanyak 100 pengunjung yang berada di dalam Taman Rekreasi Sengkaling. Jumlah responden sesuai dengan pendapat Roscoe et al. (dalam Widayat, 2004) tentang besarnya sampel. Teknik pengambilan sampel adalah purposive sampling, yaitu teknik penentuan sampel berdasarkan pertimbangan dan batasan tertentu sehingga sampel yang dipilih relevan dengan tujuan penelitian. 
Pertimbangan dan batasan tersebut mencakup sampel pengunjung kelompok usia remaja pelajar tingkat SLTA dan mahasiswa yang berkunjung ke Taman Rekreasi Sengkaling atas inisiatip sendiri, tidak ikut dalam rombongan wisatawan tertentu, tidak bersama keluarga, serta sedang berkunjung di dalam Taman Rekreasi Sengkaling pada hari Sabtu dan Minggu pada awal Maret - akhir April 2012. Data diperoleh berdasarkan respon para responden yang terpilih sebagai sampel terhadap item-item pernyataan dalam kuisioner. Responden diminta mengungkapkan responnya terhadap item-item pernyataan berdasarkan skala Likert 5 (lima) titik dari 1 (satu) "Sangat Tidak Setuju (STS) sampai dengan 5 (lima) "Sangat Setuju (SS)".

Definisi operasional experiential marketing didasarkan pada Sekar dan Kalakumari (2011), yaitu pengalaman pelanggan yang sebenarnya terhadap merek, produk/jasa yang mendorong penjualan dan meningkatkan kesadaran dan citra merek. Experiential marketing dalam penelitian ini didefinisikan sebagai pengalaman pengunjung yang sebenarnya terhadap merek, produk/jasa yang mendorong penjualan dan meningkatkan kesadaran dan citra merek Taman Rekreasi Sengkaling. Dimensi dari experiential marketing mencakup: think (berfikir); feel (perasaan); sense (indera); act (tindakan); dan relate (hubungan). Think merujuk pada pengalaman yang dirasakan atas bagaimana pengunjung memperoleh informasi kelengkapan fasilitas dan wahana rekreasi yang disediakan, dan letak strategis Taman Rekreasi Sengkaling Malang. Feel merujuk pada pengalaman rasa aman, pelayanan yang baik, dan ketepatan waktu pelayanan. Sense merujuk pada pengalaman yang ditawarkan kepada pengunjung berkaitan dengan indera penglihatan, indera perasa, indera penciuman, dan indera pendengaran. Act merujuk pada pengalaman yang ditawarkan kepada pengunjung berkaitan dengan terpenuhinya keinginan yang bersifat pribadi seperti gaya hidup, daya tanggap karyawan, dan interaksi yang baik antara karyawan dan pengunjung. Relate merujuk pada pengalaman yang ditawarkan kepada pengunjung berkaitan dengan terciptanya komunikasi langsung yang baik, pelayanan yang istimewa dari Taman Rekreasi Sengkaling Malang. Loyalitas pelanggan didefinisikan sebagai keinginan untuk datang kembali dan kesediaan memberi rekomendasi word-of-mouth (WoM) kepada orang lain tentang Taman Rekreasi Sengkaling Malang. Analisis data yang digunakan adalah regresi linier berganda, dan pengujian hipotesis 1 digunakan ANOVA (Uji-F), sedangkan pengujian hipotesis 2 digunakan Uji-t.

\section{HASIL PENELITIAN DAN PEMBAHASAN}

Kuesioner yang dibagikan kepada responden sebanyak 100 dan kembali $100 \%$ sesuai dengan rencana awal. Uji validitas dengan korelasi bivariate Pearson semua variabel yang digunakan dalam penelitian ini signifikan pada $\alpha$ (alpha) 0,01 . Sedang uji reliabilitas diperoleh nilai Cronbach alpha antara 0,72 sampai dengan 0,87 (Tabel 4), sehingga instrumen penelitian dapat dinyatakan valid dan reliabel. Uji normalitas data digunakan Kolmogorov-Smirnov (KS) Z dinyatakan berdistribusi normal (lampiran Tabel 5). Nilai cut-off tolerance lebih dari 0.10 atau VIF kurang dari 10 menunjukkan tidak ada gejala multikolinieritas (Tabel 2). Nilai Durbin-Watson (DW) sebesar 1,292 mengindikasikan tidak terdapat masalah autokorelasi. Otokorelasi terjadi jika nilai DW antara $<1$ dan $>3$ (lampiran Tabel 3). Scatterplot mengindikasikan bahwa titik-titik menyebar di atas dan di bawah angka 0 pada sumbu y, sehingga dapat dikatakan tidak terjadi heteroskedastisitas (Gambar 1).

Scatterplot

Dependent Variable: LOYALTY

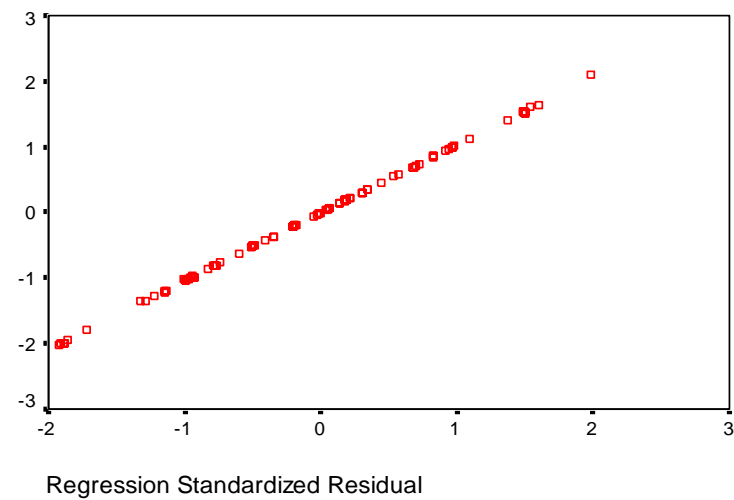

Gambar 1. Scatterplot

Analysis of variance (ANOVA) menghasilkan F-hitung sebesar 6,906 dengan signifikansi 0,00 (Tabel 1) mengindikasikan bahwa dimensi experiential marketing yang terdiri relate, feel, think, sense, dan act secara simultan berpengaruh postif dan signifikan terhadap loyalitas pengunjung Taman Rekreasi Sengkaling pada $\alpha$ (alpha) 0,01. Dengan demikian hipotesis 1 yang menyatakan "experiential marketing berpengaruh positif dan signifikan terhadap loyalitas pengunjung Taman Rekreasi Sengkaling Malang" dinyatakan dapat diterima. Temuan ini mengindikasikan bahwa pengalaman yang berkesan dari para pengunjung dapat mempengaruhi loyalitas responden untuk melakukan kunjungan ulang dan kesediaannya untuk memberi informasi word-of- 
mouth (WoM) kepada orang lain. Sebaliknya, pengalaman yang tidak berkesan dari para pengunjung dapat mempengaruhi rendahnya loyalitas responden dan rendahnya keinginan untuk melakukan kunjungan ulang dan ketidak-sediaannya untuk memberi informasi word-of-mouth (WoM) kepada orang lain. Hasil uji hipotesis 1 mengindikasikan bahwa responden Taman Rekreasi Sengkaling yang memiliki pengalaman positif cenderung memiliki sikap loyal atau memiliki niat untuk berkunjung kembali ke Taman Rekreasi Sengkaling. Sebaliknya, responden Taman Rekreasi Sengkaling yang memiliki pengalaman negatif atau tidak menyenangkan, cenderung memiliki sikap tidak loyal atau tidak memiliki niat untuk berkunjung kembali ke Taman Rekreasi Sengkaling.

Nilai Adjusted R-Square yang dihasilkan rendah, yaitu sebesar 0,23 (lampiran Tabel 3). Hal ini berarti bahwa $23 \%$ loyalitas responden dipengaruhi oleh variabel experiential marketing, sedang sisanya $77 \%$ dipengaruhi oleh variabel lain yang tidak diteliti dalam penelitian ini. Nilai adjusted R-square $23 \%$ menunjukkan bahwa experiential marketing berada pada posisi lemah dalam mempengaruhi loyalitas responden Taman Rekreasi Sengkaling. Hal ini berarti bahwa experiential marketing pada Taman Rekreasi Sengkaling memiliki basis yang lemah sehingga pengaruhnya terhadap loyalitas responden masih sangat rendah. Berdasarkan hasil tersebut, dapat dijelaskan bahwa keinginan responden untuk berkunjung kembali ke Taman Rekreasi Sengkaling cenderung rendah. Taman Rekreasi Sengkaling belum mampu menawarkan sesuai dengan apa yang dikatakan Kartajaya dan Sula (2006), bahwa perusahaan harus menawarkan produk/jasa yang mampu memberikan kesan pengalaman kepada konsumen. Tampaknya Taman Rekreasi Sengkaling, sebagaimana dikatakan Kartajaya dan Sula (2006), masih harus mempertimbangkan faktor lain selain dari experiential marketing dalam membangun loyalitas, misalnya faktor emotional branding, pshycological branding, brand trust.

Pengujian terhadap hipotesis 2 mengindikasikan bahwa secara parsial yang berpengaruh postif terhadap loyalitas responden adalah dimensi feel signifikan pada $\alpha$ (alpha) 0,01 dan dimensi sense signifikan pada $\alpha$ (alpha) 0,05 . Dimensi feel memiliki pengaruh dominan terhadap loyalitas responden disusul oleh dimensi sense. Sementara dimensi lainnya seperti think, act, dan relate tidak memiliki pengaruh signifikan terhadap loyalitas responden Taman Rekreasi Sengkaling Malang. Bahkan dimensi think dan relate pengaruhnya sangat lemah terhadap loyalitas responden (Tabel 2).

Tabel 1. ANOVA Experiential Marketing dan Loyalitas

\begin{tabular}{lcccccc}
\hline \multicolumn{1}{c}{ Model } & Sum of Squares & df & Mean Square & F & Sig. & Keterangan \\
\hline Regression & 94.310 & 5 & 18.862 & 6.906 & .000 & Hipotesis 1 diterima \\
Residual & 256.730 & 94 & 2.731 & & & \\
\hline Total & 351.040 & 99 & & & & \\
\hline
\end{tabular}

Predictors: (Constant), Relate, Feel, Think, Sense, Act

Dependent Variabel: LOYALTY

Sumber: Output SPSS Versi 10.0

Tabel 2. Koeffisien Regresi Dimensi Experiential Marketing terhadap Loyalitas

\begin{tabular}{lcccccc}
\hline \multirow{2}{*}{ Model } & $\begin{array}{c}\text { Standardized Coefficients } \\
\text { Beta }\end{array}$ & $\mathbf{t}$ & Sig. & \multicolumn{2}{c}{ Collinearity Statistics } & \multirow{2}{*}{ Keterangan } \\
\cline { 1 - 1 } (Constant) & & .594 & .554 & & & \\
THINK & .024 & .239 & .812 & .781 & 1.281 & Hipotesis ditolak \\
FEEL & .376 & 3.942 & .000 & .855 & 1.169 & Hipotesis diterima \\
SENSE & .202 & 2.065 & .042 & .813 & 1.230 & Hipotesis diterima \\
ACT & .028 & .270 & .787 & .745 & 1.342 & Hipotesis ditolak \\
RELATE & .128 & 1.400 & .165 & .932 & 1.073 & Hipotesis ditolak \\
\hline
\end{tabular}

Dependent Variabel: LOYALTY

Sumber: Output SPSS Versi 10.0

Tabel 3. Model Summary

\begin{tabular}{cccccc}
\hline Model & R & R Square & Adjusted R Square & Std. Error of the Estimate & Durbin-Watson \\
\hline 1 & .518 & .269 & .230 & 1.65 & 1.292 \\
\hline
\end{tabular}

a Predictors: (Constant), Relate, Feel, Think, Sense, Act

b Dependent Variabel: LOYAL 
Dimensi feel merujuk pada pengalaman rasa aman, pelayanan yang baik, dan ketepatan waktu pelayanan. Temuan penelitian mengindikasikan bahwa pada saat berkunjung di Taman Rekreasi Sengkaling responden memiliki rasa aman dari tindakan kriminal (tempat parkir kendaraan aman, aman dari tindakan pencopetan), dan mendapat perlindungan asuransi bila mengalami kecelakaan di dalam obyek wisata. Selama berada dalam taman rekreasi ini, responden merasa dilayani dengan baik oleh para petugas (mulai saat kendaraan masuk, antrian tiket, sampai dengan saat menikmati wahana taman rekreasi). Responden merasa bahwa pelayanan yang diberikan oleh petugas taman rekreasi ini sesuai dari sisi durasi dan ketepatan waktuknya, terutama pada saat menggunakan fasilitas yang disediakan. Dilihat dari dimensi feel, responden memperoleh pengalaman nyata yang sangat mengesankan berkaitan dengan rasa aman, pelayanan yang baik, dan ketepatan waktu pelayanan sehingga mampu membangkitkan emosi dan perasaan postif terhadap Taman Rekreasi Sengkaling.

Dimensi sense merujuk pada pengalaman yang ditawarkan kepada responden berkaitan dengan indera penglihatan, indera perasa, indera penciuman, dan indera pendengaran. Temuan penelitian mengindikasikan bahwa selama berada di dalam lingkungan Taman Rekreasi Sengkaling, responden memperoleh pengalaman yang mengesankan berkaitan dengan indera penglihatan (pepohonan dengan hijaunya dedaunan, lay-out wahana wisata yang tertata dengan baik, dan desain taman yang bagus). Responden merasa nyaman dengan kesejukan suasana taman (rindangnya pepohonan, dan air kolam yang bersih). Selama berada di dalam taman ini, responden merasa bahwa lingkungan taman ini terjaga kebersihannya dan suasananya sangat segar karena tidak terganggu oleh bebauan yang tidak sedap. Sementara itu, walaupun di dalam taman rekreasi ini diputar musik dan sering ada panggilan/ pemberitahuan kepada responden, namun responden merasa tidak terganggu dan tidak merasa terlalu bising. Dilihat dari dimensi sense, responden memperoleh pengalaman nyata yang mengesankan berkaitan dengan inderanya yang mampu membangkitkan pengalaman emosi dan perasaan postif responden terhadap Taman Rekreasi Sengkaling.

Dimensi think merujuk pada pengalaman yang dirasakan atas bagaimana responden memperoleh informasi kelengkapan dan kecukupan wahana rekreasi yang disediakan, dan letak strategis Taman Rekreasi Sengkaling Malang. Uji-t (Tabel 2) mengindikasikan bahwa dimensi think berpengaruh tidak signifikan terhadap loyalitas responden Taman Rekreasi Sengkaling. Temuan penelitian meng- indikasikan bahwa para responden cenderung memberi respon yang seragam dan cenderung ke arah kurang peduli berkaitan dengan informasi kelengkapan wahana rekreasi. Pada saat mengunjungi dan selama berada di dalam taman rekreasi, responden cenderung kurang peduli terhadap informasi yang berkaitan dengan kelengkapan wahana rekreasi. Demikian pula, responden juga cenderung kurang peduli berkaitan dengan kecukupan wahana wisata pada taman rekreasi ini. Lokasi strategis (dekat kota Malang, mudah dijangkau, dekat dengan obyek wisata lain) dari Taman Rekreasi Sengkaling Malang juga kurang menjadi pertimbangan bagi responden. Dipandang dari sudut dimensi think, pengalaman nyata dari responden tentang informasi kelengkapan dan kecukupan wahana rekreasi yang disediakan, dan lokasi yang strategis kurang menjadi pertimbangan dalam membangkitkan pengalaman emosi dan perasaan responden terhadap Taman Rekreasi Sengkaling.

Dimensi act merujuk pada pengalaman yang ditawarkan kepada responden berkaitan dengan terpenuhinya keinginan yang bersifat pribadi seperti gaya hidup, daya tanggap karyawan, dan interaksi yang baik antara karyawan dan responden. Hasil analisis regresi (Tabel 2) diperoleh koefisien regresi dimensi Act sebesar 0,028 dengan nilai t-test 0,270 dengan tingkat signifikansi 0,787. Hasil ini mengindikasikan bahwa dimensi Act berpengaruh tidak signifikan terhadap loyalitas responden pada $\alpha$ (alpha) 0,05 . Temuan ini mengindikasikan bahwa pengalaman yang ditawarkan kepada responden berkaitan dengan terpenuhinya keinginan yang bersifat pribadi seperti gaya hidup, daya tanggap karyawan, serta interaksi yang baik antara karyawan dan responden pengaruhnya sangat lemah terhadap loyalitas responden Taman Rekreasi Sengkaling.

Dimensi relate merujuk pada pengalaman yang ditawarkan kepada responden berkaitan dengan terciptanya komunikasi langsung yang baik, pelayanan yang istimewa dari Taman Rekreasi Sengkaling Malang. Hasil analisis regresi (Tabel 2) diperoleh koefisien regresi dimensi Relate sebesar 0,128 dengan nilai t-test 1,400 dengan tingkat signifikansi 0,165. Hasil ini mengindikasikan bahwa dengan menggunakan tingkat sifnifikansi $\alpha$ (alpha) 0,05 maka dimensi relate berpengaruh postif tidak signifikan terhadap loyalitas responden. Temuan ini menunjukkan bahwa pengalaman yang ditawarkan kepada responden berkaitan dengan terciptanya komunikasi langsung dan pelayanan yang baik dari Taman Rekreasi Sengkaling Malang berpengaruh sangat lemah terhadap loyalitas responden Taman Rekreasi Sengkaling. 
Tabel 4. Reliability Analysis Scale (Alpha)

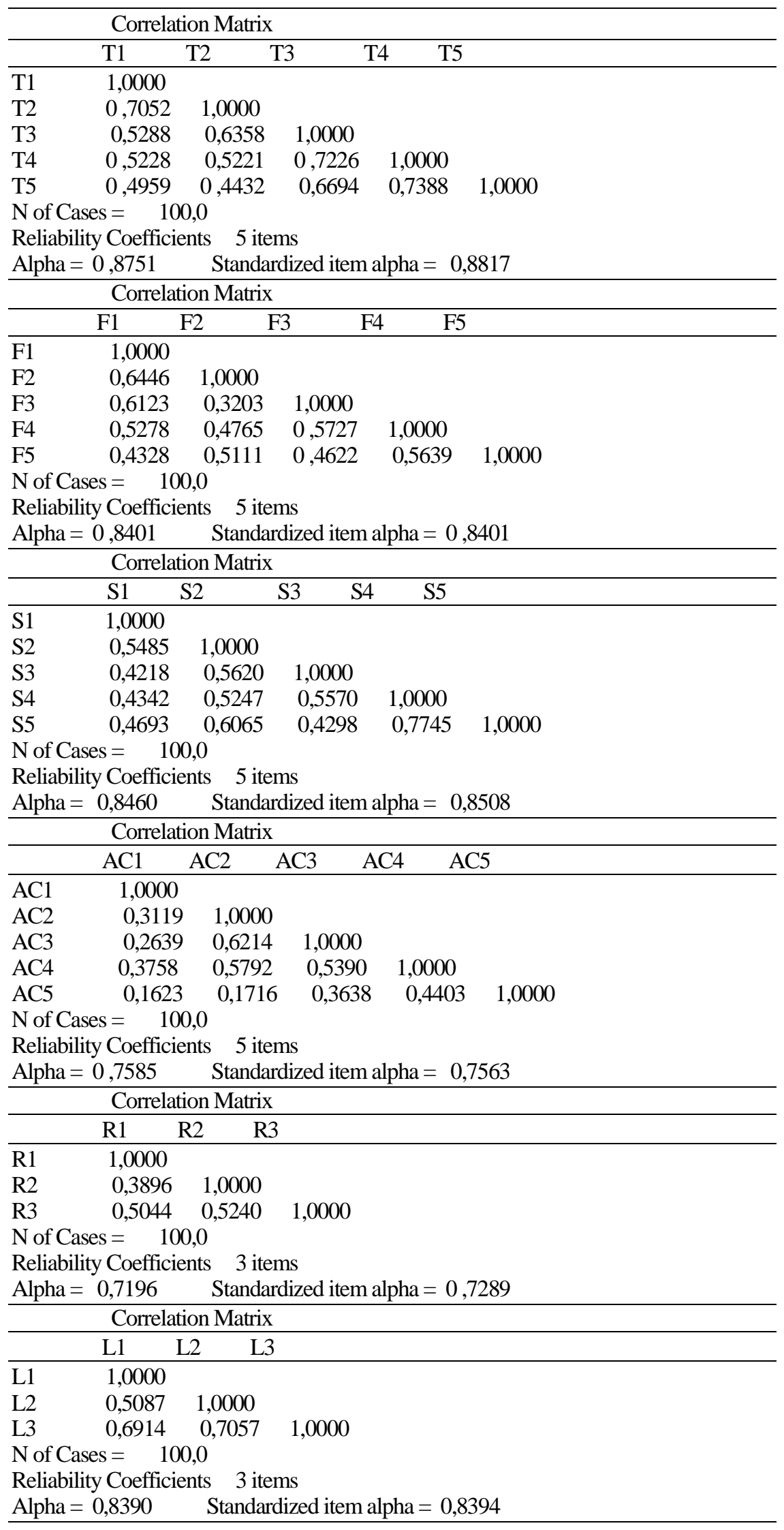


Tabel 5. Uji Normalitas

\begin{tabular}{|c|c|c|c|c|c|c|c|c|c|c|c|}
\hline & & T1 & $\mathrm{T} 2$ & T3 & $\mathrm{T} 4$ & T5 & F1 & $\mathrm{F} 2$ & F3 & F4 & F5 \\
\hline $\mathrm{N}$ & & 100 & 100 & 100 & 100 & 100 & 100 & 100 & 100 & 100 & 100 \\
\hline \multirow[t]{2}{*}{ Normal Parameters } & Mean & 3,03 & 3,07 & 3,43 & 3,18 & 3,07 & 3,28 & 3,57 & 3,51 & 3,58 & 3,47 \\
\hline & Std. Deviation & 0,96 & 0,89 & 1,06 & 0,85 & 0,69 & 1,06 & 0,88 & 0,82 & 0,87 & 0,90 \\
\hline \multirow[t]{3}{*}{ Most Extreme Differences } & Absolute & 0,218 & 0,199 & 0,198 & 0,254 & 0,271 & 0,224 & 0,292 & 0,232 & 0,236 & 0,23 \\
\hline & Positive & 0,202 & 0,191 & 0,198 & 0,254 & 0,271 & 0,224 & 0,292 & 0,232 & 0,198 & 0,188 \\
\hline & Negative & $-0,218$ & $-0,199$ & $-0,165$ & $-0,216$ & $-0,259$ & $-0,206$ & $-0,188$ & $-0,224$ & $-0,236$ & $-0,23$ \\
\hline & & 2,175 & 1,987 & 1,980 & 2,543 & 2,707 & 2,237 & 2,916 & 2,324 & 2,360 & 2,31 \\
\hline Asymp. Sig. (2-tailed) & & 0,000 & 0,001 & 0,001 & 0,000 & 0,000 & 0,000 & 0,000 & 0,000 & 0,000 & 0,00 \\
\hline
\end{tabular}

a. Test distribution in Normal

b. Calculated from data

\begin{tabular}{|c|c|c|c|c|c|c|c|c|c|c|c|}
\hline & & S1 & $\mathrm{S} 2$ & S3 & $\mathrm{S} 4$ & S5 & $\mathrm{AC} 1$ & $\mathrm{AC} 2$ & AC3 & $\mathrm{AC} 4$ & $\mathrm{AC5}$ \\
\hline $\mathrm{N}$ & & 100 & 100 & 100 & 100 & 100 & 100 & 100 & 100 & 100 & 100 \\
\hline \multirow[t]{2}{*}{ Normal Parameters } & Mean & 3,45 & 3,16 & 3,39 & 3,46 & 3,28 & 3,19 & 3,23 & 3,27 & 3,06 & 3,23 \\
\hline & Std. Deviation & 0,72 & 0,84 & 0,74 & 0,73 & 0,81 & 0,73 & 0,85 & 1,08 & 0,89 & 0,85 \\
\hline \multirow[t]{3}{*}{ Most Extreme Differences } & Absolute & 0,315 & 0,276 & 0,302 & 0,276 & 0,226 & 0,352 & 0,247 & 0,201 & 0,293 & 0,307 \\
\hline & Positive & 0,315 & 0,276 & 0,302 & 0,276 & 0,226 & 0,352 & 0,247 & 0,169 & 0,287 & 0,307 \\
\hline & Negative & $-0,215$ & $-0,274$ & $-0,218$ & $-0,230$ & $-0,224$ & $-0,318$ & $-0,193$ & $-0,201$ & $-0,293$ & $-0,283$ \\
\hline Kolmogorov-Smirnov Z & & 3,152 & 2,758 & 3,016 & 2,755 & 2,260 & 3,521 & 2,465 & 2,014 & 2,930 & 3,065 \\
\hline Asymp. Sig. (2-tailed) & & 0,000 & 0,000 & 0,000 & 0,000 & 0,000 & 0,000 & 0,000 & 0,001 & 0,000 & 0,000 \\
\hline
\end{tabular}

a. Test distribution in Normal

b. Calculated from data

\begin{tabular}{llrrrrrr}
\hline & & R1 & R2 & R3 & L1 & L2 & L3 \\
\hline Normal Parameters & & 100 & 100 & 100 & 100 & 100 & 100 \\
\hline \multirow{3}{*}{ Most Extreme Differences } & Mean & 3,28 & 3,32 & 3,05 & 3,30 & 3,28 & 3,13 \\
& Std, Deviation & 0,65 & 0,83 & 0,63 & 0,85 & 0,71 & 0,97 \\
& Absolute & 0,276 & 0,271 & 0,362 & 0,278 & 0,274 & 0,195 \\
& Positive & 0,276 & 0,271 & 0,362 & 0,278 & 0,223 & 0,173 \\
Kolmogorov-Smirnov Z & Negative & $-0,255$ & $-0,219$ & $-0,338$ & $-0,252$ & $-0,274$ & $-0,195$ \\
Asymp, Sig, (2-tailed) & & 2,761 & 2,705 & 3,618 & 2,784 & 2,741 & 1,949 \\
\hline
\end{tabular}

a. Test distribution in Normal

b. Calculated from data

\section{SIMPULAN DAN SARAN}

Penelitian ini bertujuan menganalisa dan menguji pengaruh secara simultan dan parsial dimensi experiential marketing terhadap loyalitas responden Taman Rekreasi Sengkaling Malang. Berdasarkan hasil analisis diperoleh simpulan sebagai berikut: Pertama, experiential marketing pada Taman Rekreasi Sengkaling memiliki basis yang lemah dan pengaruhnya terhadap loyalitas responden sangat rendah. Kedua, experiential marketing berpengaruh postif dan signifikan terhadap loyalitas responden. Hal ini berarti semakin kuat upaya penciptaan experiential marketing akan semakin tinggi loyalitas responden. Sebaliknya, semakin lemah upaya penciptaan experiential marketing akan semakin rendah loyalitas responden penerapan. Ketiga, dimensi feel dan sense berpengaruh postif dan signifikan terhadap loyalitas responden, sementara dimensi think, act, dan relate berpengaruh postif tidak signifikan terhadap loyalitas responden Taman Rekreasi Sengkaling Malang.

Hasil penelitian ini menunjukkan bahwa experiential marketing berpengaruh postif dan signifikan terhadap loyalitas responden. Hal ini diharapkan dapat meningkatkan kesadaran kepada para pengelola Taman Rekreasi Sengkaling untuk terus berupaya meningkatkan penciptaan pengalaman yang semakin mengesankan kepada responden. Dalam jangka panjang Taman Rekreasi Sengkaling dapat menikmati atau memperoleh pelanggan atau pengunjung yang memiliki loyalitas tinggi.

Penelitian ini mengandung keterbatasan sebagai berikut: pertama, data yang dianalisa berupa data dari kuisioner yang dibagikan kepada pengunjung yang menjadi target responden, yaitu pengunjung remaja berstatus mahasiswa dan pelajar tingkat SMU yang berada di dalam taman rekreasi. Beberapa di antara responden terlihat kurang memperhatikan item-item pernyataan kuisioner sehingga terkesan memberi 
respon sekenanya. Kedua, analisis data yang digunakan adalah regresi linier terhadap dimensi experiential marketing dan loyalitas pengunjung, sehingga tidak diketahui kuat-lemahnya pengaruh masing-masing item yang membentuk dimensi experiential marketing tersebut. Penelitian mendatang perlu diupayakan mengetahui kuat-lemahnya pengaruh setiap item yang membentuk dimensi experiential marketing maupun loyalitas melalui persamaan structural.

\section{DAFTAR REFERENSI}

Alma, B. 2011. Manajemen Pemasaran dan Pemasaran Jasa. Bandung: Penerbit Alfabeta.

Andreani, F. 2007. Experiential Marketing (Sebuah Pendekatan Pemasaran). Jurnal Manajemen Pemasaran, 2(1): 1-8.

Barnes, J. 2003. Secrets of Customer Relationship Management. Yogyakarta: Penerbit Andi.

Chen, J., Ching, R.K.H. \& Luo, M.M. 2008. Virtual Experiential Marketing on Online Customer Intentions and Loyalty. Proceedings of the $41^{s t}$ Hawaii International Conference on System Sciences, (www.computer.org/comp/, diakses 20 Februari 2012).

Febiana, S.F. 2009. Studi tentang Experiential Marketing untuk Meningkatkan Loyalitas Nasabah (Studi empiris pada PT. Bank Bukopin Tbk. Cabang Pandanaran Semarang, (eprints.undip. ac.id/24225/, diakses 10 Juli 2012).

Hasan, A. 2009. Marketing. Yogyakarta: Medpress.

Kartajaya, H. \& Sula, M.S. 2006. Syariah Marketing. Bandung: PT. Mizan Pustaka.

Lin, T.L. 2011. The Influence Factors for Visitor Loyalty on Taipei International Travel Fair, (www.jimsjournal.org/Tsung-Liang, diakses 11 Juni 2012).

Parasuraman, A., Zeithaml, V.A. \& Berry, L.L. 1988. SERVQUAL: A Multiple-Item Scale for Measuring Consumer Perceptions of Service Quality. Journal of Retailing, 24(1): 12-40.
Reinhard, H.S. 2011. Analisis Pengaruh Strategi Experiential Marketing Terhadap Customer Loyalty Pada Konsumen Toko Roti Bread Talk Sun Plaza Medan, (repository.usu.ac.id/handle/ 123456789/29015, diakses 20 Februari 2012).

Rini, E.S. 2009. Menciptakan Pengalaman Konsumen Dengan Experiential Marketing. Jurnal Manajemen Bisnis, 2(1): 1-6.

Schmitt, B. 1999. Experiential Marketing. Journal of Marketing Management, 15(3): 53-67.

Sejahtera, N.H. 2010. Analisis Pengaruh Experiential Marketing Terhadap Loyalitas Pelanggan. Skripsi Tidak Dipublikasikan. Semarang: Fakultas Ekonomi Universitas Diponegoro.

Sekar, M. \& Kalakumari, T. 2011. Experiential Marketing-Connecting Customer with Brands. Research paper. Coimbatore: Department of Commerce. Sri Krishna Arts and Science College.

Utami, M.M. 2009. Anteseden Experiential Marketing dan Konsekuensinya pada Customer's Brand Loyalty Motor Yamaha di Kota Semarang. (eprints.undip.ac.id/18159/, diakses 10 Juli 2012).

Verhoef, P.C., Lemon, K.N., Parasuraman, A., Roggeveen, A., Tsiros, M. \& Schlesinger, L.A. 2009. Customer Experience Creation: Determinants, Dynamics and Management Strategies. Journal of Retailing, 85(1): 31-41.

Widayat. 2004. Metode Penelitian Pemasaran. Surabaya: CV. Cahaya Press.

Wulan, R.I. 2003. Penataan dan Pengembangan Taman Rekreasi Sengkaling Malang. Skripsi Tidak Dipublikasikan. Semarang: Jurusan Arsitektur Fakultas Teknik Universitas Diponegoro.

Yulianto, A. 2010. Dampak Experiential Marketing Terhadap Loyalitas Pelanggan Resort Kampoeng Legok Lembang, (http://alumniunikom. ac.id, diakses 8 Maret 2012). 